\title{
Exploring the relationships among service quality features, perceived value and customer satisfaction
}

\author{
Azman Ismail ${ }^{1}$; Muhammad Madi Bin Abdullah ${ }^{2}$; Sebastian K. Francis ${ }^{3}$ \\ ${ }^{1}$ Universiti Malaysia Sarawak (MALAYSLA); ${ }^{2}$ Universiti Teknologi Malaysia International Campus \\ (MALAYSLA); ${ }^{3}$ Universiti Tunku Abdul Rabman (MALAYSLA) \\ iasman@fcs.unimas.my; mubdmadi@ic.utm.my; sebastian@utar.edu.my
}

Received January 2008

Accepted May 2009

\begin{abstract}
The purpose of this paper is to explore the relationships among service quality features (responsiveness, assurance, and empathy), perceived value and customer satisfaction in the context of Malaysia. The empirical data are drawn from 102 members of an academic staff of a Malaysian public institution of higher learning using a survey questionnaire. The results indicate three important findings: firstly, the interaction between perceived value and responsiveness was not significantly correlated with customer satisfaction. Secondly, the interaction between perceived value and assurance also did not correlate significantly with customer satisfaction. Thirdly, the interaction between perceived value and empathy correlated significantly with customer satisfaction. Thus the results demonstrate that perceived value had increased the effect of empathy on customer satisfaction, but it had not increased the effect of responsiveness and assurance on customer satisfaction. In sum, this study confirms that perceived value act as a partial moderating variable in the service quality models of the organizational sample. In addition, implications and limitations of this study, as well as directions for future research are discussed.
\end{abstract}

Keywords: service quality, perceived value, customer satisfaction, Malaysia 


\section{Introduction}

Service quality and customer satisfaction are inarguably the two core concepts that are at the crux of the marketing theory and practice (Spreng \& Mackoy, 1996). In today's world of intense competition, the key to sustainable competitive advantage lies in delivering high quality services that will in turn result in satisfied customers (Shemwell, Yavas, \& Bilgin, 1998). Therefore, there is not even an iota of doubt concerning the importance of service quality as the ultimate goal of service providers throughout the world (Sureshchandar, Rejendran, \& Anantharaman, 2002). In an era of intense global competition; many organizations have now shifted the paradigm of service quality to customer's perspective (Parasuraman, Zeithaml, \& Berry, 1985). Based on this paradigm, a customer will judge the quality of service accorded and determine whether it met his/her expectations (Grönroos, 1984; Parasuraman et al., 1985, 1988). Many scholars think that employee satisfaction with the accompanying service features may increase retention and loyalty (Alexandris, Dimitriadis, \& Makata, 2002), thus paving the way to increased organizational competitiveness (Shemwell et al., 1998).

Service quality has been defined as a form of attitude - a long-run overall evaluation (Zeithaml, 1988; Parasuraman et al., 1988) while perceived service quality as a general, overall appraisal of service. The global value judgement on the superiority of the overall service could occur at multiple levels in a particular organization (Sureshchandar et al., 2002). Many researchers such as Parasuraman et al. (1988), Juwaheer and Ross (2003) and Walker, Johnson and Leonard (2006) highlight that responsiveness, assurance and empathy as among the three most important service quality features.

Responsiveness has often been defined as the willingness of a service provider to provide the needful services accurately and promptly (Juwaheer \& Ross, 2003). Assurance refers to credibility, competence and security in delivering those services (Juwaheer \& Ross, 2003). Empathy is related to care, attention and understanding of the individual customer needs and interests when dispensing the prescriptive core services (Juwaheer \& Ross, 2003).

Extant research in this area shows that the proper implementing and dispensing of the core service quality features may justifiably increase customer satisfaction (Gronroos, 1984; Parasuraman et al., 1988; Walker et al., 2006). In a quality 
management context, customer satisfaction is defined as a result of comparison between what a customer expects about services provided by a service provider and what the customer receives in actual terms (Caruana, Money, \& Berthon, 2000; Parasuraman et al., 1988). If the service provided by an organization does meet a customer's needs and expectations, then this may subsequently lead to higher customer satisfaction (Foster, 2004; Parasuraman et al., 1988; Walker et al., 2006).

Surprisingly, a thorough investigation of such relationships reveals that the effect of service quality features on customer satisfaction is not consistent if perceived value is present in organizations (Caruana et al., 2000; Varki \& Colgate, 2001). Perceived value is considered as customer recognition and appreciation on the utility of a product that is given by a service provider which may fulfil his/her expectation (Foster, 2004; Heininen, 2004; Walker et al., 2006). In a service management framework, many researchers are in tandem that responsiveness, assurance, empathy, perceived value and customer satisfaction are distinct constructs that are highly interrelated. For example, the ability of an organisation to incorporate the use of responsiveness, assurance and empathy in the delivering services will inadvertently promote an increase in customer perceptions of value; and this in turn will motion a higher level in customer satisfaction (Parasuraman et al., 1988; Sureshchandar, 2000; Sureshchandar et al., 2002).

Even though many studies have been carried out in this area of research, little is known about the moderating effect of perceived value in service quality models. Most studies have found that the mediating role of perceived value has been less emphasized in previous quality system research. This is because of an over emphasis of a segmented approach in analyzing service quality features, the heavy reliance on a direct effect model testing, and negligence pertaining to the role of human needs and expectations in developing previous service quality models (Bitner, 1990; Caruana et al., 2000). Consequently, the findings from such research approaches may not highlight the influence of perceived value as a moderating variable in service quality literature (Eggert \& Ulaga, 2002; Sureschchandar et al., 2002).

The current study has three major research questions: first, which features of service quality may affect customer satisfaction? Second, which features of service quality may affect perceived value? Finally, does perceived value affect the 
relationship between service quality features and customer satisfaction? Hence, this study is conducted to measure three main objectives: first, the relationship between the service quality features and customer satisfaction. Second, the relationship between the service quality features and perceived value. Lastly, the moderating effect of perceived value in the relationship between service quality features and customer satisfaction that occurs in one selected Malaysian public university in East Malaysia. For confidential reasons, the name of the institution is kept anonymous.

The remaining discussions of this paper are structured as follows: first, to elaborate the related literature review and research hypotheses. Second, to describe the methodology and procedure involved in conducting the study; and finally to discuss the results of hypothesis testing and conclusion.

\section{Literature review and research hypotheses}

Several studies about soft quality programs in Western organizational settings show that service quality may both, directly and indirectly, affect customer satisfaction. In terms of direct relationship perspective, Bitner (1990) examined the quality service based on a sample of 145 tourists and found that service quality was an important antecedent of customer satisfaction. In addition, Caruana et al. (2000) conducted a research comprising 80 personal interviews with customers of an audit firm and found that service quality positively correlated with perceived value. Hence, it can be hypothesized that:

- $\mathrm{H} 1$ : There is a positive relationship between responsiveness and customer satisfaction

- H2: There is a positive relationship between assurance and customer satisfaction

- H3: There is a positive relationship between empathy and customer satisfaction

- H4: There is a positive relationship between responsiveness and perceived value 
- H5: There is a positive relationship between assurance and perceived value

- H6: There is a positive relationship between empathy and perceived value

Further, recent research in this area has revealed that the relationship between service quality and customer satisfaction is strongly moderated by perceived value. For example, Eggert and Ulaga (2002) conducted a study on customer satisfaction of 301 employees in US organizations. The study finds that properly implemented service quality features (i.e., assurance, empathy, reliability, responsiveness and tangibles) have increased individual perceived value. As a result, it probably can contribute to an increased level of customer satisfaction.

The service quality research literature is consistent with the notion of perceived quality models. For example, Parasuraman et al. (1985) state that a conceptual service quality model highlights that the match between service quality standards and customers' standards may decrease service performance gap and increase customer perceived value about the quality systems. Consequently, it may lead to higher customer satisfaction. This literature has been used to develop the conceptual framework for this study as shown in Figure 1.

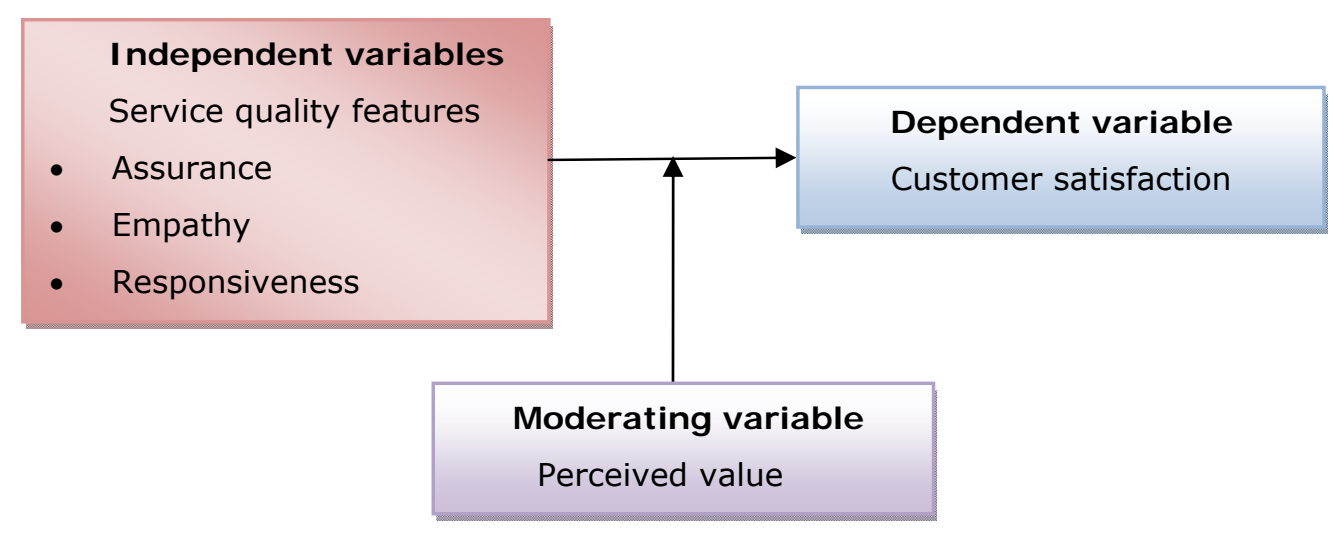

Figure 1. "Perceived value as a moderator on the relationships between service quality features and customer satisfaction"

Based on the framework, it can be hypothesized that: 
- H7: Perceived value moderates the relationships between service quality features and customer satisfaction

\section{Methodology}

\subsection{Research design}

This study used a cross-sectional research design which allowed the researchers to integrate service quality literature, in-depth interviews, a pilot study and the actual survey as the main procedure to gather accurate and less bias data (Davis, 1996; Cresswell, 1998; Sekaran, 2000). This study was conducted in a selected public institution of higher learning in East Malaysia (HIGHINSTITUTION), where a center for teaching and learning (central teaching building) has been established to develop and manage sophisticated teaching and learning facilities for the educational institution. This center uses teaching and learning quality standards set by the Ministry of Higher Education, Malaysia, to establish and manage lecture theatres and lecture halls in the target educational institution.

In order to understand the nature of quality service, in-depth interviews are first conducted involving four experienced officers comprising of an assistant registrar, an information systems manager, an assistant administrative officer and a supporting staff. All of them are currently in active employment at the center. They are selected based on purposive sampling where the employees possess adequate knowledge and experience in the area of designing and administering quality service programs. The information garnered from such employees has helped the researchers to understand the nature of quality service policies and procedures, employees' perceptions of value about service quality and customer satisfaction characteristics, as well as the relationships between such variables in the target institution. After refining, categorizing and comparing the information with relevant theoretical and empirical evidence, the information was used as a guideline to develop the content of survey questionnaires for a pilot study. Next, the pilot study is conducted by discussing survey questionnaires with five experienced academic staff with a sound background knowledge and experience in social sciences, humanities, sciences and technology. The information is then used to verify the content and format of a survey questionnaire for the actual research. 


\subsection{Measures}

Back translation technique was used to translate the content of the questionnaire in Malay and English in order to increase the validity and reliability of the instrument (Wright, 1996). The survey questionnaire was developed based on the modification of SERVQUAL instrument (Parasuraman et al., 1985). This questionnaire consists of three major sections: firstly, responsiveness was measured using 4 items. The items used to measure this variable are (1) repair teaching and learning facilities, (2) assist academic staff in operating teaching and learning facilities, (3) booking system for lecture halls and/or lecture theatres and (4) ready to assist academic staff if needed. Secondly, assurance was measured using 3 items. The items used to measure this variable are (1) confidence in the service provider, (2) comfortable in dealing with the service provider and (3) efficiency in providing services. Thirdly, empathy was measured using 3 items. The items used to measure this variable are (1) understandable about academic staffs' needs; (2) put a priority in monitoring central teaching buildings and (3) ability in fulfilling the requests of the academic staff.

Fourthly, perceived value has 3 items that have been modified from service quality related perceived value (Caruana et al., 2000; Foster, 2004). The items used to measure this variable are (1) teaching and learning facilities are useful for teaching and learning, (2) teaching and learning facilities help to improve teaching and learning and (3) teaching and learning spaces are comfortable for teaching activities. Fifthly, customer satisfaction has 4 items that are modified from service quality related customer satisfaction (Bitner, 1990; Eggert \& Ulaga, 2002; Walker et al., 2006). The items used to measure this variable are satisfaction or dissatisfaction with (1) the service provider's attitude and behavior, (2) the ability of the service provider's treatment of the academic staff, (3) the ability of the service provider to communicate with the academic staff and (4) the willingness of the service provider to maintain the teaching and learning conditions of the central teaching buildings. All these items are measured using a 7-point Likert scale ranging from 'very strongly disagree' (1) to 'very strongly agree' (7). Demographic variables are used as a controlling variable because this study is focused on employee attitude. 


\subsection{Sample}

The unit of analysis for this study is the 800 members of the academic staff who are in employment at the HIGHINSTITUTION in East Malaysia. In the first step of data collection procedure, the researchers met the university's HR department to find out about the rules for distributing the survey questionnaire to the academic staff. Considering the organizational rule, a quota sampling was used to determine the sample size based on the length of the study and the budget constraint involving the 120 academic staff. Further, a convenient sampling technique was used to distribute the 120 questionnaires to the academic staff of all the faculties at the main campus of the university. From that number, a total of 102 survey questionnaire were returned to the researchers yielding an 84 percent response rate. The survey questionnaire were answered by the participants by consent and on a voluntarily basis.

\subsection{Data analysis}

A statistical package for social sciences (SPSS) version 15.0 was used to analyze the data from the questionnaire. Firstly, exploratory factor analysis (EFA) was used to assess the validity and reliability of measurement scales (Hair, Anderson, Tatham, \& Black, 1998). Secondly, Pearson correlation analysis ( $r$ ) and descriptive statistics were conducted to determine the collinearity problem and the usefulness of the data set. Finally, a hierarchical regression analysis, as recommended by Cohen and Cohen (1983), was used to measure the moderating effect of perceived value in the hypothesized model. Moderating effect is an interaction that shows the degree of relationship between the independent variables and dependent variables and that will change if other variables exist in the relationship (Cohen \& Cohen, 1983; Jaccard, Turrisi, \& Wan, 1990). The results of an interaction are evident when the relationship between interacting terms and the dependent variable is significant. The fact that the significant main effects of predictor variables and moderator variables simultaneously exist in analysis it does not affect the moderator hypothesis and is significant to interpret the interaction term (Baron \& Kenny, 1986). 


\section{Results}

\subsection{Sample profile}

In relation to the sample profile, Table 1 shows the following characteristics: 1 ) the majority of the respondents are females $(58.8 \%) ; 2)$ the respondents are mainly between the ages of 31 and 35 years old $(54.9 \%)$; 3) many of them possess a masters' degree $(80.4 \%)$; their length of service range from 4 to 7 years $(49.0 \%)$, and most of the lecturers have an educational background in social sciences and humanities $(58.0 \%)$.

\begin{tabular}{llc}
\hline General Characteristics & \multicolumn{1}{c}{ Sub Characteristics } & Percentage \\
\hline Sex & Male & 41.2 \\
Age & Female & 58.8 \\
& Less than 30 years & 20.6 \\
& $31-35$ years & 54.9 \\
& $36-40$ years & 16.7 \\
Education & More than 40 years & 7.8 \\
& Bachelor & 9.8 \\
Masters & 80.4 \\
Length of service & PhD/Professional doctorate & 9.8 \\
& Less than 3 years & 19.6 \\
& $4-7$ years & 49.0 \\
& 8-11 years & 26.5 \\
Field of study & 12-15 years & 2.9 \\
& More than 15 years & 2.0 \\
& Social sciences and humanities & 58.8 \\
& Sciences and technology & 41.2 \\
\hline
\end{tabular}

Table 1. "Profile of respondents $(\mathrm{N}=102)$ "

Analysis of variance techniques (t-test and ANOVA) are used to compare the mean scores between the two or more groups in the target institution. In this case, the independent samples t-tests are used to compare two different (independent) groups of people (i.e. gender) and ANOVA is used to compare three and more different (independent) groups of people (i.e. age). Further, if ANOVA results are significant, post-hoc comparison (Tukey honestly significant differences) (HSD) will be used to determine which groups are significantly different in relation to one another (Pallant, 2001; Zukarnain \& Hishamuddin, 2001). 
Table 2 shows that gender has no significant difference, which means that responsiveness, assurance, empathy, perceived value and customer satisfaction, are not differently perceived by females and males.

\begin{tabular}{|l|c|c|}
\hline \multicolumn{1}{|c|}{ Gender } & t-Value & Mean Difference \\
\hline Responsiveness & -1.40 & -.18 \\
\hline Assurance & -1.52 & .24 \\
\hline Empathy & -.95 & .16 \\
\hline Perceived Value & -1.37 & -.52 \\
\hline Customer Satisfaction & -1.34 & -.28 \\
\hline \multicolumn{2}{|c|}{ Note: Significant at $* \mathrm{p}<0.05 ; * * \mathrm{p}<0.01 ; * * * \mathrm{p}<0.001$} & \\
\hline
\end{tabular}

Table 2. "Independent Samples T-Test for the Differences between Gender".

Table 3 shows that age does not have a significant difference, meaning that responsiveness, assurance, empathy, perceived value and customer satisfaction are not differently perceived by age structures. Thus, post-hoc tests do not show the differences among the age structures.

\begin{tabular}{|c|c|c|c|c|c|}
\hline Variable & & $\begin{array}{l}\text { Sum of } \\
\text { Squares }\end{array}$ & Df & Mean Square & $\mathbf{F}$ \\
\hline Responsiveness & $\begin{array}{l}\text { Between Groups } \\
\text { Within Groups } \\
\text { Total }\end{array}$ & $\begin{array}{c}.99 \\
40.95 \\
41.94\end{array}$ & $\begin{array}{c}3 \\
98 \\
101\end{array}$ & $\begin{array}{l}.33 \\
.42\end{array}$ & .79 \\
\hline Assurance & $\begin{array}{l}\text { Between Groups } \\
\text { Within Groups } \\
\text { Total }\end{array}$ & $\begin{array}{c}1.09 \\
61.53 \\
62.62\end{array}$ & $\begin{array}{c}3 \\
98 \\
101\end{array}$ & $\begin{array}{l}.36 \\
.63\end{array}$ & .58 \\
\hline Empathy & $\begin{array}{l}\text { Between Groups } \\
\text { Within Groups } \\
\text { Total }\end{array}$ & $\begin{array}{c}.70 \\
69.52 \\
70.22\end{array}$ & $\begin{array}{c}3 \\
98 \\
101\end{array}$ & $\begin{array}{l}.23 \\
.71\end{array}$ & .33 \\
\hline Perceived Value & $\begin{array}{l}\text { Between Groups } \\
\text { Within Groups } \\
\text { Total }\end{array}$ & $\begin{array}{c}1.01 \\
63.59 \\
64.60\end{array}$ & $\begin{array}{c}3 \\
98 \\
101\end{array}$ & $\begin{array}{l}.34 \\
.65\end{array}$ & .52 \\
\hline $\begin{array}{l}\text { Customer } \\
\text { Satisfaction }\end{array}$ & $\begin{array}{l}\text { Between Groups } \\
\text { Within Groups } \\
\text { Total }\end{array}$ & $\begin{array}{c}1.18 \\
34.19 \\
35.37\end{array}$ & $\begin{array}{c}3 \\
98 \\
101\end{array}$ & $\begin{array}{l}.39 \\
.35\end{array}$ & 1.12 \\
\hline
\end{tabular}

Note: Significant at $* \mathrm{p}<0.05 ; * * \mathrm{p}<0.01 ; * * * \mathrm{p}<0.001$

Table 3. "The Results of One-Way ANOVA for the Difference between Age Structures". 


\subsection{Validity and reliability analyses for measurement scales}

The validity and reliability analyses were conducted based on the procedures established by Hair et al. (1998), and Nunally and Bernstein (1994). A principal component factor analysis with oblique rotation using direct oblimin was used to determine the possible dimensions of the constructs. Furthermore, the KaiserMayer-Olkin Test (KMO) which is a measure of sampling adequacy was conducted for each variable and the results indicate that it was acceptable. The original survey questionnaire has 38 items which are related to five variables: responsibility ( 7 items), assurance ( 7 items), empathy ( 7 items), perceived value ( 7 items) and customer satisfaction (10 items). The factor analysis was conducted to condense the 38 items to 17 items.

\begin{tabular}{cccccccc}
\hline Measures & Item & $\begin{array}{c}\text { Factor } \\
\text { Loadings }\end{array}$ & KMO & $\begin{array}{c}\text { Bartlett's Test of } \\
\text { Sphericity }\end{array}$ & Eigenvalue & $\begin{array}{c}\text { Variance } \\
\text { Explained }\end{array}$ & $\begin{array}{c}\text { Cronbach } \\
\text { Alpha }\end{array}$ \\
\hline Responsiveness & 4 & $0.62-0.89$ & 0.78 & $180.25, \mathrm{p}=.0005$ & 2.76 & 68.97 & 0.85 \\
Assurance & 3 & $0.60-0.90$ & 0.63 & $118.20, \mathrm{p}=.0005$ & 2.15 & 71.70 & 0.80 \\
Empathy & 3 & $0.47-0.60$ & 0.66 & $98.50, \mathrm{p}=.0005$ & 2.12 & 70.62 & 0.78 \\
$\begin{array}{c}\text { Perceived Value } \\
\quad \text { Customer }\end{array}$ & 3 & $0.62-0.89$ & 0.78 & $180.25, \mathrm{p}=.0005$ & 2.76 & 68.97 & 0.85 \\
\begin{tabular}{c} 
Satisfaction \\
\hline
\end{tabular} & & $0.60-0.90$ & 0.63 & $118.20, \mathrm{p}=.0005$ & 2.15 & 71.70 & 0.80 \\
\hline
\end{tabular}

Table 4. "Results of validity and reliability analyses".

Table 4 shows the results of the validity and reliability analyses where (1) all research variables exceeded the minimum standard of Kaiser-Meyer-Olkin's value of 0.6 and are significant in Bartlett's test of sphericity (BTS), (2) all research variables had eigenvalues larger than $1,(3)$ the items for each variable exceeded factor loadings of 0.40 (Hair et al., 1998), and (4) all variables exceeded the acceptable standard of reliability analysis of 0.70 (Nunally and Bernstein, 1994). These statistical results support the notion of the perceived value theories (Parasuraman et al., 1985), and empirical studies (Eggert and Ulaga, 2002; Varki and Colgate, 2001), signifying the goodness of data for this study.

\subsection{Correlation and regression analysis}

As depicted in Table 5, the mean value for each variable is between 5.01 and 5.43, indicating the level of responsiveness, assurance and empathy, perceived value and customer satisfaction ranging from a level of high (4) to highest (7). The Pearson correlation coefficients between the independent variables (i.e., 
responsiveness, assurance and empathy) and moderating variable (i.e., perceived value) and between dependent variable (i.e., customer satisfaction) are less than 0.90 , indicating the data are not affected by serious collinearity problem (Hair et al., 1998). These correlations also provide further evidence of validity and reliability for measurement scales used in this research (Hair et al., 1998).

Table 5 shows the results of testing two direct effect hypotheses: first, the relationship between service quality features and customer satisfaction, and second, the relationship between service quality features and perceived value. The outcome of testing the first type of relationship shows three important findings: 1 ) responsiveness is positively and significantly related to customer satisfaction $(r=.47, p<0.01)$, therefore $\mathrm{H} 1$ is supported. 2) assurance is positively and significantly related to customer satisfaction $(r=.35, p<0.01)$, therefore $H 2$ is supported. 3) empathy is positively and significantly related to customer satisfaction $(r=.53, p<0.01)$, therefore $\mathrm{H} 3$ is supported. These statistical results show that the three service quality characteristics are important predictors of customer satisfaction in the organizational sample.

Besides that, the outcomes of testing the second type of relationship also display three important findings: 1 ) responsiveness is positively and significantly related to perceived value $(r=.47, p<0.01)$, therefore $\mathrm{H} 4$ is supported. 2) assurance is positively and significantly related to perceived value $(r=.35, p<0.01)$, therefore $\mathrm{H} 5$ is supported. 3) empathy is positively and significantly related to perceived value $(r=.56, p<0.01)$, therefore $\mathrm{H} 6$ is supported. These statistical results show that the three service quality characteristics are important antecedents of perceived value in the organizational sample.

\begin{tabular}{|c|c|c|c|c|c|c|c|}
\hline \multirow[t]{2}{*}{ Variables } & \multirow[t]{2}{*}{ Mean } & \multirow{2}{*}{$\begin{array}{l}\text { Standard } \\
\text { Deviation }\end{array}$} & \multicolumn{5}{|c|}{ Pearson Correlation } \\
\hline & & & 1 & 2 & 3 & 4 & 5 \\
\hline 1. Responsiveness & 5.22 & 0.64 & (1) & & & & \\
\hline 2. Assurance & 5.10 & 0.78 & $0.51 * *$ & (1) & & & \\
\hline 3. Empathy & 5.01 & 0.83 & $0.55^{* *}$ & $0.64 * *$ & (1) & & \\
\hline $\begin{array}{l}\text { 4. Perceived } \\
\text { Value }\end{array}$ & 5.25 & 0.79 & $0.47 * *$ & $0.35 * *$ & $0.56 * *$ & (1) & \\
\hline $\begin{array}{l}\text { 5. Customer } \\
\text { Satisfaction }\end{array}$ & 5.43 & 0.59 & $0.59 * *$ & $0.54 * *$ & $0.53 * *$ & $0.50 * *$ & (1) \\
\hline
\end{tabular}

Table 5. "Pearson correlation coefficients between variables and descriptive statistics". 


\begin{tabular}{|c|c|c|c|}
\hline \multirow{2}{*}{ Variables } & \multicolumn{3}{|c|}{ Customer Satisfaction } \\
\hline & Model 1 & Model 2 & Model 3 \\
\hline \multicolumn{4}{|l|}{ Controlling Variables } \\
\hline Sex & 0.28 & 0.09 & 0.10 \\
\hline Age & 0.06 & -0.02 & 0.02 \\
\hline Education & 0.17 & 0.18 & 0.15 \\
\hline Length of service & -0.07 & -0.10 & -0.08 \\
\hline Faculty & 0.09 & 0.13 & 0.13 \\
\hline \multicolumn{4}{|l|}{ Independent Variables } \\
\hline Responsiveness & & 0.35 & 0.39 \\
\hline Assurance & & 0.25 & 1.45 \\
\hline Empathy & & 0.07 & -1.05 \\
\hline Perceived Value & & 0.18 & 0.57 \\
\hline \multicolumn{4}{|l|}{ Moderating Variables } \\
\hline Responsiveness $\mathrm{x}$ Perceived Value & & & -0.22 \\
\hline Assurance $\mathrm{x}$ Perceived Value & & & -1.83 \\
\hline Empathy $\times$ Perceived Value & & & $1.72 *$ \\
\hline$R^{2}$ & 0.10 & 0.53 & 0.56 \\
\hline $\mathrm{R}^{2}$ Adjusted & 0.05 & 0.48 & 0.49 \\
\hline $\mathrm{F}$ & 2.14 & $11.46 * * *$ & $9.34 * * *$ \\
\hline $\mathrm{R}^{2}$ Change & 0.10 & 0.43 & 0.03 \\
\hline $\mathrm{F} \Delta \mathrm{R}^{2}$ & 2.14 & $20.90 * * *$ & 1.93 \\
\hline
\end{tabular}

Table 6: "Results for hierarchical regression analysis with perceived value as the moderating variable and customer satisfaction as the dependent variable".

Table 6 shows the outcome of testing the moderating hypotheses in Model 3. Firstly, the interacting variable (responsiveness $x$ perceived value) is insignificantly and negatively correlated with customer satisfaction $(\beta=-0.22, p>0.05)$, therefore $\mathrm{H} 1$ is rejected. This result demonstrates that the inclusion of perceived value has not increased the effect of responsiveness on customer satisfaction. This indicates that perceived value does not act as a moderating variable in such relationships. Secondly, the interacting variable (assurance $x$ perceived value) is also insignificantly and negatively correlated with customer satisfaction $(\beta=-1.83$, $\mathrm{p}>0.05)$, therefore $\mathrm{H} 2$ is also rejected. This result demonstrates that the inclusion of perceived value has not increased the effect of assurance on customer satisfaction. This indicates that perceived value does not act as a moderating variable in such relationships. Thirdly, the interacting variable (empathy $x$ perceived value) is significantly and positively correlated with customer satisfaction 
$(\beta=1.72, p<0.05)$, therefore $\mathrm{H} 3$ is accepted. This result demonstrates that the inclusion of perceived value has increased the effect of empathy on customer satisfaction. This indicates that perceived value does act as a positive moderating variable in such relationships.

\section{Discussion and conclusion}

The finding for this research shows that perceived value does act as a partial moderating variable in the relationship between service quality features and customer satisfaction. In the context of HIGH INSTITUTION, Malaysia the service provider (center for teaching and learning) is given a major responsibility to plan, maintain, and monitor sophisticated teaching and learning facilities (i.e., lightings, air-conditioners, computers, multimedia and physical equipments) in the central teaching buildings based on the rules set up by the leadership of the university. In general, a majority of the academic staff perceived that implementation of such service quality practices has improved the delivery of teaching and learning services and this may invoke their perceived value about the quality systems. Specifically, a majority of the academic staff perceived that their values about the use of empathy in delivering teaching and learning services might be an important predictor of customer satisfaction. Conversely, a majority of the academic staff perceived that their values about the use of responsiveness and assurance in delivering teaching and learning services might not be major antecedents of customer satisfaction.

A thorough review of the in-depth interview reveals that perceived value does not moderate the effect of responsiveness and assurance on customer satisfaction; this may be caused by external factors. Firstly, the teaching and learning facilities in the central teaching buildings are intensively used from morning till night within learning semesters for the purposes of teaching and conducting seminars, short courses and workshops. If these teaching and learning facilities are not properly utilized, they may not be repaired or replaced with other equipment within a short time. The duration of repairing and/or replacing with other equipment will be longer; and this may increase the academic staffs' complaints and criticisms of the service provider.

Secondly, as a new campus, the teaching and learning facilities in the central teaching buildings have been properly installed and managed by the service 
provider. For example, the service provider is given a major responsibility to provide teaching and learning aids for specific purposes such as teaching, conducting seminars, short courses and workshops. Although the service provider may provide teaching and learning equipment, it does not have sufficient equipment to meet the expectations of the academic staff. Besides that, the service provider does not have enough sufficient manpower and therefore will not be able monitor and maintain the equipment needed if there are many functions held at several of the lecture theatres and lecture halls in the central teaching buildings. The inability to manage such teaching and learning facilities may decrease the desired comfort, trust and courtesy of the academic staff when teaching and organizing seminars, short courses and workshops in the central teaching buildings. As a result, it may increase feelings of dissatisfaction and misjudgment about the services from among the members of the academic staff.

This study provides significant implications and impacts on three major aspects: theoretical contribution, robustness of research methodology, and practical contribution. In terms of theoretical contribution, the findings of this study provide three important elements: firstly, perceived value does positively moderate the relationship between empathy in teaching and learning services on customer satisfaction. In this sense, the inclusion of perceived value in the analysis has increased the effect of empathy in teaching and learning services on customer satisfaction. This finding is consistent with previous studies by Eggert and Ulaga (2002) and Varki and Colgate (2001). Secondly, perceived value does not moderate the relationship between responsiveness in the delivery of teaching and learning services on customer satisfaction. This result shows that the inclusion of perceived value in the analysis has not increased the effect of responsiveness in teaching and learning services on customer satisfaction. This finding is consistent with studies by Caruana et al. (2000) and Eggert and Ulaga (2002). Thirdly, perceived value also does not moderate the relationship between assurance in the delivery of teaching and learning services on customer satisfaction. This result demonstrates that the inclusion of perceived value in the analysis has not increased the effect of assurance in the teaching and learning services on customer satisfaction. This finding is not consistent with previous study by Eggert and Ulaga (2002). In sum, this study has extended previous research conducted in most Western countries and provided a great potential to understand the notion of 
positive contribution of perceived value in the HIGH INSTITUTION-service quality model.

Regarding the robustness of the research methodology, the data gathered using service quality literature, the in-depth interviews, pilot study and survey questionnaire have exceeded the minimum standard of validity and reliability analyses and this can lead to the production of accurate and reliable findings.

With respect to practical contributions, the findings of this study can be used as a guideline by the management to improve the design and administration of service quality programs in organisations. Specifically, the design and management of service quality may be improved if managers emphasize on the suggestions: firstly, staff who are involved in providing teaching and learning facilities need to be engaged in proper quality management training programs. Through these training programs, the staff will have the opportunity to acquire new knowledge, skills, abilities, as well as be imbued with good moral values. Consequently, these learning outcomes may be used to increase efficiency when engaged in current and future job undertakings. Secondly, staff members who are involved in providing teaching and learning facilities need to be given better rewards. For example, those who are involved in improving teaching and learning facilities are from the low level positions and who are eligible to do overtime. In this situation, providing extra monetary incentives to them will invoke their satisfaction and this may lead to increased motivation to perform their jobs better. Thirdly, recruitment policy needs to be changed from hiring fresh employees to experienced employees. For example, staff members who are involved in providing teaching and learning facilities are usually dealing with professional employees. If organization hires experienced staff this will encourage them to minimize errors and increase efficiency in installing, maintaining and monitoring sophisticated teaching and learning facilities. As a result, it may lead to an improved customer service and customer satisfaction.

Fourthly, staff performance need to be properly assessed. For example, members who are involved in providing teaching and learning facilities deal with backgrounds clients from varied background. The nature of their work requires different performance appraisal styles. For example, immediate boss and customers views should be used to determine accurate performance ratings. As a result, it may lead to increased staff motivation in the workplace. 
If organisations seriously consider such suggestions then this will help the academic staff to improve their teaching and learning activities. This in turn will motivate students' motivation to acquire new knowledge, skills, abilities and good moral values. Consequently, it may lead to enhance the effectiveness of teaching and learning in the universities.

The conclusions drawn from the results of this study should consider the following limitations. Firstly, this study was a cross-sectional research design where the data was taken at one point of time within the duration of this study. In this sense, this research design did not capture the developmental issues (e.g., intra-individual change and restrictions of making inference to participants) and/or causal connections between variables of interest. Secondly, this study only examined the relationship between latent/unobserved variables (i.e., responsiveness, assurance, empathy, perceived value and customer satisfaction) and the conclusion drawn from this study does not specify the relationship between specific indicators for the independent variables, moderating variable, and dependent variable. Thirdly, the outcomes of multiple regression analysis have focused on the level of performance variation explained by the regression equations and it is also helpful to indicate the amount of dependent variable variation that is not explained (Tabachnick \& Fidell, 2001). Although a substantial amount of variance in dependent measure that is explained by the significant predictors is identified, there are still a number of unexplained factors that can be incorporated to identify the causal relationships among variables and their relative explanatory power. Therefore, one should be cautious about generalising the statistical results of this study. Finally, the sample of this study uses only the academic staff from a single university and they are selected by using a convenient sampling technique. The nature of this sample may decrease the ability of generalizing the results of this research to other organisational settings.

The conceptual and methodological limitations of this study need to be considered when designing future research. Firstly, this study sets up a foundation for research on relationships between service qualities, perceived value and customer satisfaction. It has raised many questions as well as confirming initial propositions. A few research areas can be further explored as a result of this study. Secondly, the organisational and personal characteristics as a potential variable that can influence perceived value about service quality needs to be further explored. Using 
these organisational (e.g., ownership and type) and personal (e.g., gender, age, education and position) characteristics may provide meaningful perspectives for the understanding of how individual similarities and differences affect service quality policies within an organisation. Thirdly, the cross-sectional research design has a number of shortcomings; therefore other research designs such as longitudinal studies could be used as a procedure for collecting data and describing the patterns of change and the direction and magnitude of causal relationships between variables of interest. Fourthly, the findings of this study rely too much on the sample taken from a single organizational sector. To fully understand the effects of service quality on individual attitudes and behaviour via its impact upon perceived value, more organisational sectors (e.g., government linked companies, business organizations, and non-profit organizations) need to be used in future study. Finally, other personal outcomes of perceived value such as retention, loyalty and commitment should be considered in future research because they are given more attention in considerable service quality literature (Alexandris et al., 2002; Parasuraman et al., 1988; Walker et al., 2006). The importance of these issues needs to be further explained in future research.

In sum, the findings of this study confirm that perceived value does act as a partial moderating role in the service quality model of the organisation. These results have partially supported and broadened service quality research literature published in most Western countries. Therefore, current research and practice within service quality models needs to consider individuals' perceived value as a critical aspect of service quality. The findings of this study further suggests that perceived value should be seen as a crucial aspect of service quality where perceived value about service quality may strongly induce positive subsequent personal outcomes (e.g., satisfaction, retention, commitment and thus loyalty). Thus, it may lead employees to maintain and increase academic excellence in higher learning institutions.

\section{Acknowledgment}

An earlier version of this paper was presented at the Borneo Research Council 9th Biennial International Conference, 29-30 July 2008, Kota Kinabalu, Sabah, Malaysia. 


\section{References}

Alexandris, K, Dimitriadis, N., \& Makata, D. (2002). Can perceptions of service quality predict behavioural intentions? An exploratory study in the hotel sector in Greece, Managing Service Quality, 12(4), 224-231.

Baron, R.M., \& Kenny, D.A (1986). This moderator-mediator variable distinction in social psychological research: Conceptual, strategic and statistical considerations, Journal of Personality and Social Psychological, 51, 1173-1182.

Bitner, M.J. (1990). Evaluating service encounters: the effects of physical surroundings and employee response, J ournal of Marketing, 2, 69-82.

Caruana, A., Money, A.H., \& Berthon P.R. (2000). Service quality and satisfaction the moderating role of value, European Journal of Marketing, 34(11/12), 13381352.

Cohen, J., \& Cohen, P. (1983). Applied multiple regression/correlation analysis for the behavioural sciences. Hillsdale, NJ: Lawrence Erlbaum.

Creswell, J. W. (1998). Quality inquiry and research design: choosing among five traditions. London: SAGE Publication.

Davis, D. (1996). Business Research for Decision Making. (4 ${ }^{\text {th }}$ ed.). Belmont: Duxbury Press.

Eggert, A., \& Ulaga, W. (2002). Customer perceived value: a substitute for satisfaction in business markets? Journal of Business and Industrial Marketing, $17(2 / 3), 107-118$.

Foster, S. T. (2004). Managing Quality: An Integrative Approach. New Jersey: Prantice Hall.

Gonroos, C. (1984). A service quality model and its market implications, European Journal of Marketing, 18(4), 36-44.

Hair, J.F., Anderson, R.E., Tatham, R.L., \& Black, W.C. (1998). Multivariate data analysis. ( $5^{\text {th }}$ ed.). New Jersey: Prentice-Hall International, Inc. 
Heininen, K. (2004). Reconceptualizing customer perceived value: the value of time and place, Managing Service Quality, 14(2/3), 205-215.

Jaccard, J., Turrisi, R., \& Wan, C.K (1990). Interaction effects in multiple regression. Newsbury Park, California: SAGE Publications, inc.

Juwaheer, T. D., \& Ross, D. L. (2003). A study of guest perceptions in Mauritius. International J ournal of Hospitality Management, 15(2), 105-115.

Nunally, J.C. \& Bernstein, I.H. (1994). Psychometric Theory. New York: McGrawHill.

Parasuraman, A., Zeithaml, V. A., \& Berry, L. L. (1985). A conceptual model of service quality and its implication for future research, Journal of Marketing, No.49, 41-50.

Parasuraman, A., Zeithaml, V. A., \& Berry, L. L. (1988). SERVQUAL: a multipleitem scale for measuring consumer perceptions of service quality, Journal of Retailing, 64(1), 12-40.

Sekaran, U. (2000). Research methods for business: A skill building approach. New York: John Wiley and Sins, Inc.

Shemwell, D.J., Yavas, U., \& Bilgin Z. (1998). Customer-service provider relationships: an empirical test of a model of service quality, satisfaction and relationship oriented outcome, International Journal of Service Industry Management, 9, 155-168.

Spreng, R.A., \& Mackoy, R.D. (1996). An empirical examination of a model of perceived service quality and satisfaction, Journal of Retailing, 72, 201-214.

Sureshchandar, G.S. (2000). Development of a framework for total quality service - the case of banks in India. Unpublished doctoral dissertation, Indian Institute of Technology Madras.

Sureshchandar, G.S., Rajendran, C., \& Anantharaman, R. N. (2002). The relationship between service quality and customer satisfaction - a factor specific approach, J ournal of Services Marketing, 16(4), 363-379. 
Tabachnick, B.G., and Fidell, L.S. (2001). Using multivariate statistics. Sydney: Allyn and Bacon.

Varki, S., \& Colgate, M. (2001). The role of price perceptions in an integrated model of behavioural intentions, Journal of Service Research, 3(3), 232-40.

Walker, R. H., Johnson, L.W., \& Leonard, S. (2006). Re-thinking the conceptualization of customer value and service quality within the service-profit chain, Managing Service Quality, 16(1), 23-36.

Wright, I.L. (1996). Quality International management Research. In Punnett, B.J. and Shenkar, O. Handbook for International Management Research (pp. 63-81). Oxford, UK: Blackwell Publishers Inc.

Zeithaml, V. A. (1988). Consumer perceptions of price, quality, and value: a means-end model and synthesis of evidence, J ournal of Marketing, 52, 2-22.

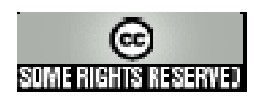

Article's contents are provided on a Attribution-Non Commercial 3.0 Creative commons license. Readers are allowed to copy, distribute and communicate article's contents, provided the author's and Journal of Industrial Engineering and Management's names are included. It must not be used for commercial purposes. To see the complete license contents, please visit http://creativecommons.org/licenses/by-nc/3.0/. 